\title{
Oviposition behaviour of Gryon gallardoi (Hymenoptera, Scelionidae) on eggs of different ages of Spartocera dentiventris (Hemiptera, Coreidae)
}

\author{
Luciane da Rocha ${ }^{1}$, Luiza Redaelli ${ }^{1} \&$ Milton de S. Mendonça $\mathrm{Jr}^{2}$
}

1. Departamento de Fitossanidade, Faculdade de Agronomia, Universidade Federal do Rio Grande do Sul (UFRGS), Av. Bento Gonçalves 7712,91540-000 Porto Alegre, RS, Brasil. (lucianerrocha@yahoo.com.br/luredael@ufrgs.br)

2. Departamento de Zoologia e Genética, Instituto de Biologia, UFPel, Campus Universitário s/n, Caixa Postal 354, $96010-900$ Pelotas, RS, Brasil (milton.mendonca@ufpel.edu.br)

\begin{abstract}
The oviposition behaviour of Gryon gallardoi (Brèthes, 1914) on eggs of Spartocera dentiventris (Berg, 1884) of different ages $(2,3,4,5,6,7,8$ and 12 days) was investigated. Groups of 12 eggs of each age were exposed to single females of $G$. gallardoi, and the oviposition behaviour was recorded under a stereomicroscope for two hours. Ten replicates were used for each age. In order to identify the moment the parasitoid egg was released inside the host, 1-day old eggs of $S$. dentiventris were exposed to G. gallardoi females, and the oviposition was interrupted at intervals of 20,40,60,80,100,120,140 and 160s after ovipositor insertion had initiated. Five behavioural steps were recorded: drumming, ovipositor insertion, marking, walking and resting. The average drumming and ovipositor insertion times increased with the host age $(\mathrm{P}<0.01)$. Ovipositor insertion usually occurred next to the longitudinal extremities of the host eggs. Marking took on average $19.5 \pm 0.7 \mathrm{~s}$, and as walking and resting, was not affected by host age. Self-parasitism behaviour was observed in only $13.8 \pm 2.3 \%$ of the eggs, being more evident with increasing patch depletion (reduction in non-parasitized eggs in the egg group, $\mathrm{P}<0.01$ ), again with no variation due to changes in host egg age. For all ages tested, self-parasitized host eggs were less frequently contacted and accepted than non-parasitized ones $(\mathrm{P}<0.01)$. The parasitoid egg was released $137.0 \pm 3.7 \mathrm{~s}$ after ovipositor insertion. Spartocera dentiventris egg condition can lead to parasitoid behavioural changes, especially during the process of host choice and discrimination.
\end{abstract}

KEYWORDS. Scelionidae, parasitoid, behaviour, host selection.

RESUMO. Comportamento de oviposição de Gryon gallardoi (Hymenoptera, Scelionidae) sobre ovos de diferentes idades de Spartocera dentiventris (Hemiptera, Coreidae). Este trabalho objetivou investigar o comportamento de oviposição de Gryon gallardoi (Brèthes, 1914) sobre ovos de Spartocera dentiventris (Berg, 1884) de diferentes idades $(2,3,4,5,6,7,8$ e 12 dias). Grupos de 12 ovos de cada idade foram expostos a uma fêmea de G. gallardoi, e o comportamento de oviposição registrado sob um esteremicroscópio por duas horas. Foram feitas dez repetições para cada idade. Para identificar o momento em que o ovo do parasitóide é liberado dentro do hospedeiro, ovos de $S$. dentiventris de um dia de idade foram expostos para fêmeas de G. gallardoi, sendo a oviposição interrompida nos intervalos de 20,40,60,80,100,120, 140 and 160s após a inserção do ovipositor. Foram registrados cinco processos comportamentais: tamborilamento, inserção do ovipositor, marcação, caminhada e descanso. O tempo médio de tamborilamento e de inserção do ovipositor aumentou com a idade do hospedeiro $(\mathrm{P}<0,01)$. A inserção do ovipositor ocorreu, na maioria das vezes, nas extremidades longitudinais dos ovos. A marcação durou, em média, $19,5 \pm 0,7 \mathrm{~s}$, e assim como a caminhada e o descanso, não foi influenciada pela idade do hospedeiro. O comportamento de auto-parasitismo não foi influenciado pela idade do hospedeiro e foi observado somente em $13,8 \pm 2,3 \%$ dos ovos, sendo mais evidente à medida que o número de ovos não-parasitados no grupo diminú́a $(\mathrm{P}<0,01)$. Em todas as idades testadas, ovos autoparasitados foram menos contatados e menos aceitos pelo parasitóide $(\mathrm{P}<0,01)$. O ovo do parasitóide foi liberado após 140 e $160 \mathrm{~s}$ após a inserção do ovipositor. Os resultados sugerem que a condição dos ovos de $S$ dentiventris pode acarretar em mudanças comportamentais no parasitóide, especialmente durante o processo de escolha e discriminação dos mesmos.

PALAVRAS-CHAVE. Scelionidae, parasitóide, comportamento, seleção de hospedeiros.

The study of parasitoid oviposition behaviour is of fundamental importance to an understanding of the processes involved in host selection and acceptance and to the development of biological control programmes ( $\mathrm{P}_{\mathrm{AK}}$, 1986; ORR, 1988; HiguCHI \& SUZUKI, 1996; VINSON, 1998). In this context, a series of researches have been developed worldwide, both with egg parasitoids of solitary or semi-gregarious habits (STRAND \& VINSON, 1983; NAVASERO \& OATMAN, 1989; COLAZZA et al., 1996; CONTI et al., 1997; Rosi et al., 2001; Solis et al., 2001; HIROSE et al., 2003; Wiedemann et al., 2003; Dasilao \& Arakawa, 2004) and with those of gregarious habits (PAK et al., 1986; SCHIMIDT \& SMith, 1987; Hintz \& ANDOw, 1990; RUBERson \& KRING, 1993).

In many egg parasitoids, host selection can be done based on host age, because of the influence of age on the host nutritional value (Izumi et al., 1994). Host age can lead to changes in behaviour during the selection process, reflecting chemical and physiological changes occurring during host development (GODFRAY, 1994).

According to VINSON (1998), egg parasitoids exhibit at least three characteristic behaviours: host inspection with antennae (drumming), obtaining chemical and/or physical information from the host; ovipositor insertion, involving chorion perforation, oviposition site choice and sometimes the release of chemical substances inhibiting host development (poisoning), followed by egg release; and finally marking, involving deposition of chemical substances or mechanical markings (ridges) over the parasitized egg, to avoid superparasitism.

The oviposition behaviour of many Scelionidae species was already described by different authors 
(Strand \& Vinson, 1983; CAVE et al., 1987; OrR et al., 1986; Navasero \& OATMAn, 1989; Colazza et al., 1996; Higuchi \& SuzuKi, 1996; WeBer et al., 1996; Romeis et al., 2000; Rosi et al., 2001; HiRose et al., 2003), however there are few sources associating behavioural changes to modifications in host condition and quality.

Gryon gallardoi (Brèthes, 1914) is referred as an important parasitoid associated to the coreids Spartocera lativentris (Stål, 1870) (LOIÁCONO, 1980; BECKER \& PRATO, 1982), Spartocera dentiventris (Berg, 1884) (SANTOs et al., 2001) and Leptoglossus zonatus (Dallas, 1852) (SouZA \& Amaral-Filho, 1999; Marchiori \& Penteado-Dias, 2002).

Spartocera dentiventris is a tobacco (Nicotiana tabacum Linnaeus, 1753) pest in Rio Grande do Sul state, southern Brazil, causing leaf wilting and rolling, due to its phytophagous sucking habit (SCHAEFER \& PANIzZI, 2000). Field studies developed by SANTOS et al. (2001) showed that G. gallardoi is responsible for $70 \%$ of $S$. dentiventris mortality, on average, in the egg stage.

Solis et al. (2001) evaluated oviposition behaviour in G. gallardoi, for mated females with oviposition experience, on eggs of L. zonatus. The authors recorded six behavioural processes: host selection, choice of ovipositor insertion point, oviposition, marking, cleaning and resting.

Wiedemann et al. (2003) described, in the laboratory, the oviposition behaviour of G. gallardoi on one day-old $S$. dentiventris eggs. Five distinct behaviours were recorded: drumming, ovipositor insertion, egg marking, walking and resting. This study, besides evidencing behaviours common to other scelionids, demonstrated that egg marking is a good indicator of effective oviposition and can avoid superparasitism.

Given the behavioural variations that can occur in parasitoids as a function of host quality, this work aimed to evaluate, in the laboratory, whether females of $G$. gallardoi change their behaviour when exposed to eggs of different ages of $S$. dentiventris. Aspects relating to ovipositor insertion point, self-parasitism and the precise moment the parasitoid egg is released inside the host were also taken into consideration.

\section{MATERIAL AND METHODS}

All insects used in the present study were obtained from an experimental tobacco plantation ( $N$. tabacum), in which $S$. dentiventris rearing begun from naturally occurring adults of the colonising generation. The moment coreid eggs were identified on the tobacco plants, some females were individually confined in cages to obtain egg groups of known age. All other females were kept free in the area so as to obtain parasitized eggs.

Parasitized eggs found in the culture were taken to the laboratory to start rearing of G. gallardoi. Parasitoids were kept in transparent plastic cages under controlled conditions $\left(25 \pm 1^{\circ} \mathrm{C}\right.$ and $12 \mathrm{~h}$ photoperiod) until adult emergence. Adult parasitoids used in the experiments were kept under these same conditions and fed on a 10\% honey solution (WIEDEMANN et al., 2003)

We used mated parasitoid females between two and five days of age, kept confined with egg groups of $S$. dentiventris for 24 hours to acquire oviposition experience. Afterwards, each female was exposed individually and without choice to a non-parasitized egg group of each of the following ages: $2,3,4,5,6,7,8$ and 12 days, in a test tube $(1 \times 6 \mathrm{~cm})$ closed with a cotton stopper. Ten females were used, individually, for each $S$. dentiventris egg age. To record behaviour, a map of each egg group offered was drawn, so that each egg could be individually identified. Observations were done with the aid of a stereomicroscope with cold light, during two hours, from the moment the female first manifested interest in the egg group. For each egg group of a given age, the behavioural processes of the G. gallardoi female were recorded according to the classes proposed by WiedemAnN et al. (2003), with the description and duration of each process obtained vocally with the help of a tape recorder and chronometer. Self-parasitism was recorded as so when a female of $G$. gallardoi inserted the ovipositor and marked an egg more than once (WIEDEMANN et al., 2003), with behaviours toward these eggs also recorded.

To estimate the moment of egg release by females of G. gallardoi during ovipositor insertion, 1-day old $S$. dentiventris eggs were offered in a test tube to a 2 to 5 day-old experienced female. Oviposition was interrupted after defined intervals $(20,40,60,80,100,120,140$ and 160 seconds), counted from the moment ovipositor insertion was detected. One female was used for each insertion and 20 replicates for each interval. Eggs were individualized and followed until parasitism was confirmed (egg colour changes to grey).

Data referring to oviposition behaviour were transformed to $\log (\mathrm{x})$ and submitted to regression analysis. For the comparison between behaviours towards parasitized and self-parasitized eggs in different ages an ANCOVA was used. Given data normality (Kolmogorov-Smirnov test) and homocedasticity (Bartlett test), ovipositor insertion site for each egg group of a different age was analysed with a one-way ANOVA (Newman-Keuls test); the same procedures were used to analyse parasitized egg fate in the different moments after oviposition interruption, with comparisons using the Tukey test at 5\% significance.

\section{RESULTS AND DISCUSSION}

For all ages of $S$. dentiventris eggs, G. gallardoi females showed the following behavioural processes: drumming, ovipositor insertion, marking, walking and resting. Such processes corroborate those observed for G. gallardoi by Solis et al. (2001) in eggs of L. zonatus and WiEDEMANN et al. (2003) on one-day-old eggs of $S$. dentiventris, being similar to other gryonineans as Gryon cravigrallae Mineo, 1984 (RomeIs et al., 2000), Gryon obesum Masner, 1983 (Hirose et al., 2003) and Gryon philippinense (Ashmead, 1904) (DASILAO \& ArAKAWA, 2004).

Drumming time of G. gallardoi females tended to increase with host egg age $\left(\mathrm{F}_{1,971}=166.68 ; \mathrm{R}^{2}=14.65 \%\right.$; $\mathrm{P}<0.001)$ (Fig. 1) with the shortest time $(78.9 \pm 16.1 \mathrm{~s})$ 
recorded for two-day-old eggs and the longest (201.7 \pm $26.3 \mathrm{~s})$ to 12 -day-old. The low value for $\mathrm{R}^{2}$ in the regression analysis could be linked to the fact that from two to eight day-old eggs drumming time did not vary much (Fig. 1), with a difference most evident for 12-dayold eggs, causing a degree of leverage. Thus, it could be suggested that females spend more time examining eggs of extremely advanced ages.

In the egg region where drumming stopped, the ovipositor was inserted. For all egg ages tested, most of the time, females inserted the ovipositor in the longitudinal ends $(85.0 \pm 0.04 \%$, being $51.0 \pm 2.3 \%$ of the times in the pseudoperculum and $34.4 \pm 2.3 \%$ in the opposite end). Other insertions were done in the median lateral region $(13.7 \pm 7.1 \%)$ and on top of the eggs $(4.88 \pm 3.4 \%)$. These differences in ovipositor insertion site were significant $\left(\mathrm{F}_{3,27}=61.83 ; \mathrm{P}<0.001\right)$. The average time a female remained with the ovipositor in the host tended to increase with host egg age $\left(\mathrm{F}_{1.841}=168.25 ; \mathrm{R}^{2}=17.18 \% ; \mathrm{P}<0.001\right)$ (Fig. 2$)$, with the shorter time on two-day-old eggs $(169.4 \pm 9.3 \mathrm{~s})$ and the longest on 12-day-old eggs $(254.1 \pm 9.1 \mathrm{~s})$.

The marking process begun after the ovipositor was retreated and consisted of the female brushing the posterior region of the abdomen over all the egg surface in backwards lateral movements. For all ages evaluated, marking occurred in $81.9 \pm 6.06 \%$ of the eggs in which ovipositor insertion was recorded. Marking time did not vary with host egg age $\left(\mathrm{F}_{1.686}=0.017 ; \mathrm{R}^{2}=0.0001 \% ; \mathrm{P}=\right.$ 0.89 ) being on average $19.5 \pm 0.7 \mathrm{~s}$.
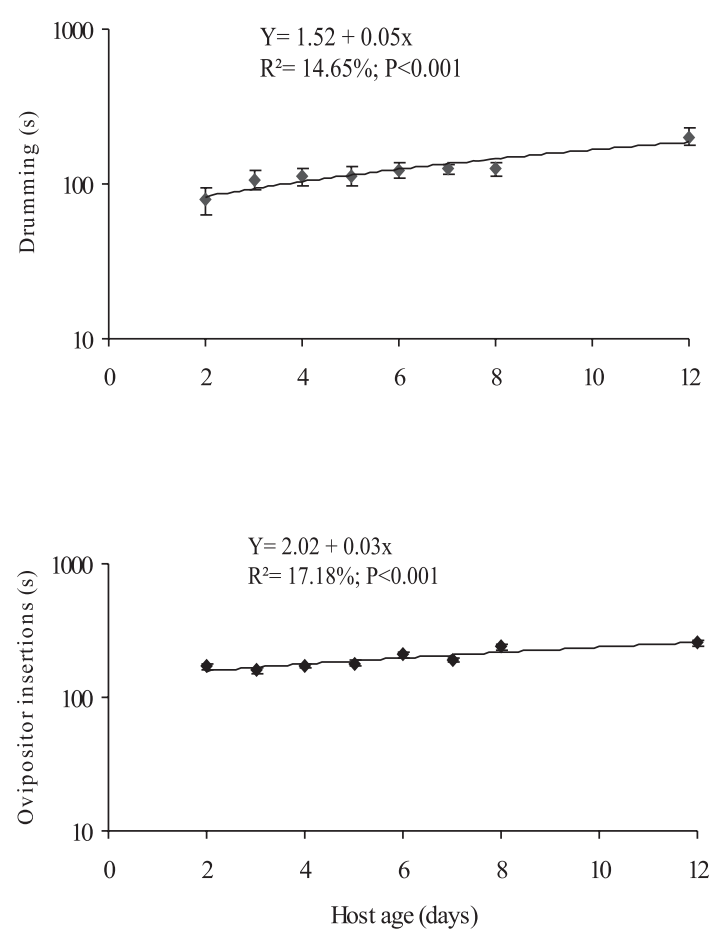

Figs. 1, 2. Average duration (s) ( \pm s.e) of the oviposition behaviour stages of Gryon gallardoi (Brèthes, 1914) on eggs of Spartocera dentiventris (Berg, 1884): 1, drumming; 2, ovipositor insertion (bars indicate standard errors).
Walking was characterized when the female showed no interest in the host egg group, walking over them without antennal contact or on the test tube walls. Resting occurred when the female stayed with antennae withdrawn, either when she was on the egg group or on the test tube wall. Neither behaviour evidenced significant variation relative to host egg age $\left(\mathrm{F}_{1,125}=1.13 ; \mathrm{R}^{2}=0.07 \%\right.$; $\mathrm{P}=0.77$ and $\mathrm{F}_{1,64}=1.64 ; \mathrm{R}^{2}=1.74 \% ; \mathrm{P}=0.29$, respectively for walking and resting). The average duration of these behaviours, considering all egg ages, was $647.0 \pm 83.3 \mathrm{~s}$ and $493.0 \pm 91.0 \mathrm{~s}$, respectively, for walking and resting.

Change in behaviour as a function of host age is also seen in other families of egg parasitoids. PAK et al. (1986) recorded such variations on eggs of different ages (zero to three days) of three lepidopterans: Mamestra brassicae (Linnaeus, 1758) (Noctuidae), Pieris brassicae (Linnaeus, 1758) and Pieris rapae (Linnaeus, 1758) (Pieridae), where handling time of Trichogramma spp. females was longer for older eggs. In Ooencyrtus nezarae (Ishii, 1977) (Hymenoptera, Encyrtidae), TAKASU \& HIROSE (1993) observed that time spent in host-feeding and ovipositor insertion increased with increases in egg age of Riptortus clavatus (Thunberg, 1783) (Hemiptera, Alydidae), as well as total handling time.

Such behavioural changes in parasitoids can be related to the process of host quality evaluation, which is supposedly inversely associated to host age. According to VINSON (1998), changes in behaviour related to host age can be due to alterations in the chemical stimuli, the physical stimuli (shape, colour, size, resonance, among others) or physical conditions (membranous barriers) assessed by the wasps when recognizing and accepting hosts. In the Scelionidae, various sources demonstrate host acceptance to occur only given appropriate chemical stimuli (STRAND \& VINSON, 1983; Bin et al., 1993), and many of these stimuli can become less evident with host age, implying in increased difficulty for host recognition (VINSON, 1998). Studies done by StRAND \& Vinson (1983) showed that Telenomus heliothidis (Ashmead, 1853) (Hymenoptera, Scelionidae) detects host age through antennal drumming, using host egg format of Heliothis virecesns (Fabricius, 1777) (Lepidoptera, Noctuidae), which becomes less spherical and more conical with increases in age.

In the present study, the increase in ovipositor insertion time with host egg age can be connected directly to egg composition, since it passes from simple reserve nutrients to more complex tissues chemically and morphologically. Thus, a parasitoid female could face a problem finding an adequate oviposition site within the host or perhaps having to release larger quantities of substances to delay or inhibit egg development (poisoning). Marking time on the S. dentiventris eggs by the parasitoid does not seem to change with host age, however, according to Colazza et al. (1996), the occurrence and marking method can differ among parasitoid species and host conditions, being even absent in some cases. HIROSE et al. (2003) showed that G. obesum females mark only zero to two-day-old eggs of the host Euschistus conspersus Uhler, 1897 (Hemiptera, Pentatomidae). Older eggs, of four to five days, were not 
marked, fact attributed by the authors to the failure in parasitism of such older eggs.

Over all ages tested, the average percentage of selfparasitism was of $13.8 \pm 2.3 \%$, with no variation with egg age $\left(\mathrm{R}^{2}=2.00 \% ; \mathrm{gl}=58 ; \mathrm{P}=0.1943\right)$. A highly significant quadratic polynomial regression revealed that selfparasitism was more evident between the $9^{\text {th }}$ and $17^{\text {th }}$ ovipositor insertion, which coincides with the decrease in available non-parasitized eggs $\left(\mathrm{F}_{1,82}=10.74 ; \mathrm{R}^{2}=21.6 \%\right.$; $\mathrm{P}<0.001$ ) (Fig. 3). The decrease in self-parasitism on subsequent ovipositions coincides on its turn with the end of the observations, when the female was loosing interest on the eggs (Fig. 3).

Handling time for self-parasitized eggs (including drumming, ovipositor insertion and marking), when compared to the handling time of non-parasitized eggs, was not significantly different $\left(\mathrm{F}_{1,168}=0.12 ; \mathrm{P}>0.05\right)$. However, for all ages a smaller number of contacts (visits) to self-parasitized eggs was detected $\left(\mathrm{F}_{1,122}=\right.$ 178.76; $\mathrm{P}<0.01$ ) (Fig. 4) as well as a lower percentage of acceptance (ovipositor insertion, followed by marking) $\left(\mathrm{F}_{1,120}=57.13 ; \mathrm{P}<0.01\right)$ (Fig. 5), strengthening the pattern for $G$. gallardoi females actively avoiding selfparasitism.

Even though acceptance of already parasitized eggs was low, self-parasitism can still occur because of a series of factors, as inefficient marking, low non-parasitized host density (VINSON, 1998), female inexperience in ovipositing (HubBARD et al., 1999) and/or high parasitoid density on the same host (s) (Wu \& NordLund, 2002). According to ALPHEN \& VISSER (1990), self-parasitism is more frequent in laboratory confined individuals with a limited number of hosts, being imposed by the reduction in nonparasitized eggs and by the decrease in time involved in searching.

For many egg parasitoid species, as Trichogramma evanescens (Westwood, 1833) (Hymenoptera, Trichogrammatidae) (SALT, 1934), Telenomus sphingis (Ashmead, 1884) (Hymenoptera, Scelionidae) (RABB \& Bradley, 1970) and Anaphes iole (Girault, 1911) (Hymenoptera, Mymaridae) (CoNTI et al., 1997), drumming time is longer on previously parasitized eggs. Results obtained in the present study and by the cited authors

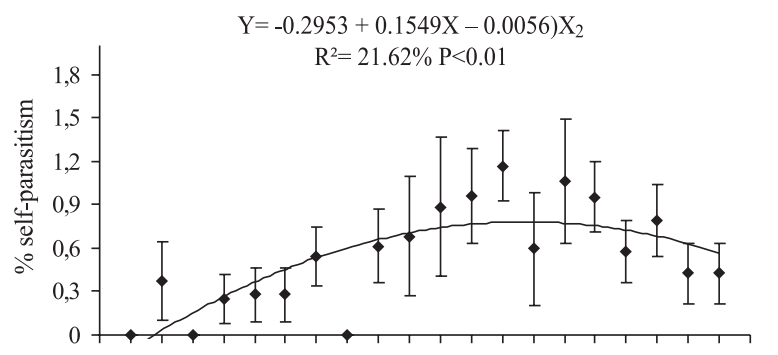

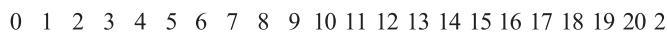
egg oviposition order

Fig. 3. Percentage self-parasitism average ( \pm s.e) for females of Gryon gallardoi (Brèthes, 1914) according to the order of oviposition on eggs of Spartocera dentiventris (Berg, 1884) (bars indicate standard errors). suggest that parasitoid females are able to distinguish parasitized from non-parasitized eggs and that this reflects on their behaviour, with an option for self-parasitism only when the number of hosts becomes scarce.

Regarding egg release during ovipositor insertion, the higher percentages of parasitized eggs from which parasitoid adults effectively emerged occurred in the interval of 140 to 160 s after ovipositor insertion $(\mathrm{F}=62.84$; $\mathrm{P}<0.01$ ) (Fig. 6). For the other intervals of oviposition interruption, offered eggs turned into $S$. dentiventris nymphs or failed (neither nymph nor parasitoid resulted). According to STRAND \& VINSON (1983), this would be justifiable since egg release through the ovipositor can be in itself a stimulus for the beginning of marking. Thus, our results suggest that $G$. gallardoi females, in the time between ovipositor insertion and egg release, could be obtaining information on host quality, choosing an adequate site for oviposition and/or releasing poisoning substances. Similarly, in other Scelionidae species as $T$. heliothidis, egg release occurs at the end of the ovipositor insertion period, on the seconds just before marking (STRAND \& VINSON, 1983).

The results here presented suggest that $S$. dentiventris egg condition, both in terms of age and previous parasitism, can modify the oviposition behaviour by $G$. gallardoi. Females of the latter species can discriminate among different host conditions, especially through drumming, which in adaptive terms is of extreme importance for offspring survival. However, spending a longer time examining hosts of older ages means a higher energetic cost, perhaps even compromising this species efficiency for biological control programmes.
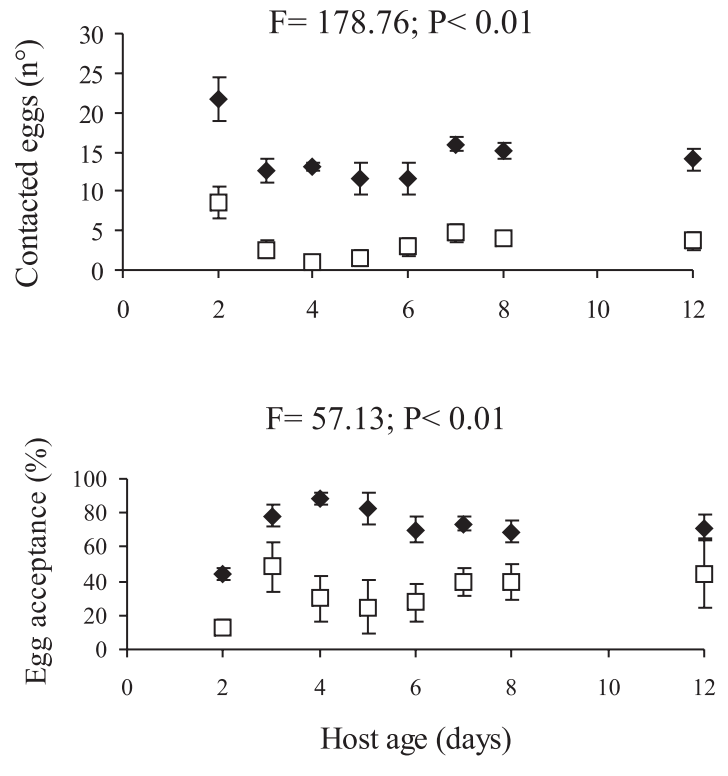

- Non-parasitized $\square$ Self-parasitized

Figs. 4, 5. Compared oviposition behaviour (average \pm s.e) of Gryon gallardoi (Brèthes, 1914) on self-parasitized and nonparasitized eggs of different ages of Spartocera dentiventris (Berg, 1884): 4, number of contacts; 5 , percentage of acceptance. 


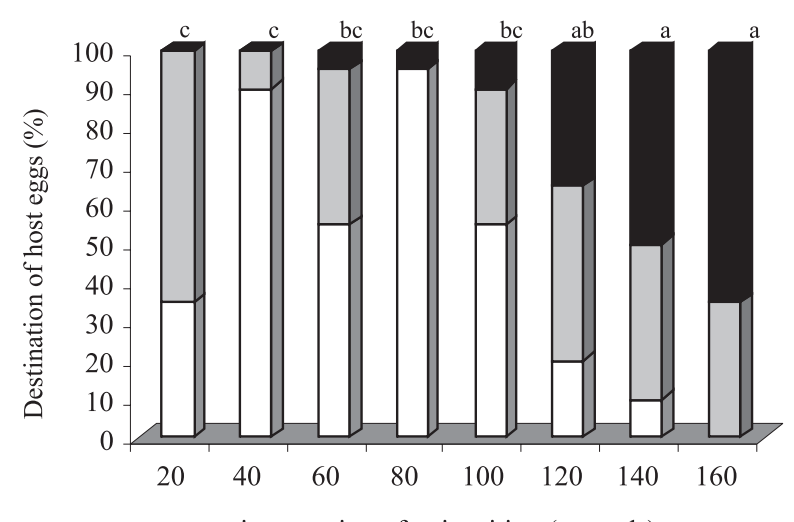

interruption of oviposition (seconds)

\section{nymphs $\square$ failed $\square$ parasitized}

Fig. 6. Destination of host eggs (\%) of Spartocera dentiventris (Berg, 1884) (Coreidae) relative to periods of oviposition interruption (s) for females of Gryon gallardoi (Brèthes, 1914) (Scelionidae) (bars folowed by different letters differ for the Tukey test at $5 \%$ ).

Acknowledgments. We thank $\mathrm{CNPq}$ for a research grant (process no. 471097/01-2) and for scholarships to the authors. MSMJ was supported by ProDoc/CAPES.

\section{REFERENCES}

Alphen, J. J. M. van \& Visser, M. E. 1990. Superparasitism as an adaptative strategy for insect parasitoids. Annual Review of Entomology 35:59-79.

Becker, M. \& Prato, M. D. 1982. Natality and natural mortality of Spartocera lativentris Stal 1870 (Heteroptera: Coreidae) in the egg stage. Anais da Sociedade Entomológica do Brasil 11:1344-1348.

Bin, F.; Vinson, S. B.; Strand, M. R.; Colazza, S. \& Jones, W. A. 1993. Source of an egg kairomone for Trissolcus basalis, a parasitoid of Nezara viridula. Physiology Entomological 18:7-15.

Cave, R. D.; Gaylor, M. J. \& Bradley, J. R. 1987. Host handling and recognition by Telenomus reynoldsi (Hymenoptera: Scelionidae) an egg parasitoid of Geocoris spp. (Heteroptera: Lygaeidae). Annals of the Entomological of America 80(2):217-223.

Colazza, S.; Rosi, M. C.; Sebastiani, P. \& Ursini, M. 1996. Host acceptance behaviour in the egg parasitoid Trissolcus basalis (Hymenoptera: Scelionidae). Acta Ecologica 17(2): 109-125.

Conti, E.; Walker, A. J.; Bin, F. \& Vinson, S. B. 1997. Oviposition behavior of Anaphes iole, an egg parasitoid of Lygus hesperus (Hymenoptera: Mymaridae; Heteroptera: Miridae). Annals of the Entomological of America 90(1):91-101.

Dasilao, A. O. \& Arakawa, R. 2004. Reproductive capacity and host handling behavior of Gryon philippinense (Asmead) (Hymenoptera: Scelionidae), a solitary egg parasitoid of the winter cherry bug, Acanthocoris sordius Thunberg (Hemiptera: Coreidae). Applied Entomology and Zoology 39(2):263-269.

Godfray, H. C. J. 1994. Parasitoids Behavioral and Evolutionary Ecology. Princeton, Princeton University. 473p.

Higuchi, H. \& Suzuki, Y. 1996. Host handling behaviour of the egg parasitoid Telenomus triptus to the egg mass of the stink bug Piezorus hybneri. Entomologia Experimentalis et Applicata 80:475-479.

Hintz, J. L. \& Andow, D. A. 1990. Host age and host selection by Trichogramma nibilale. Entomophaga 35:41-150.

Hirose, Y.; Ehler, L. E. \& Hirose, Y. 2003. Influence of host age on patch use by a quasi-gregarious egg parasitoid.
Environmental Entomology 32(4):789-796.

Hubbard, S. F.; Harvey, I. F. \& Fletcher, J. P. 1999. Avoidance of superparasitism: a matter of learning? Animal Behaviour 57:1193-1197.

Izumi, S.; Yano, K.; Yamanomoto, Y. \& Takahashi, Y. 1994. Yolk proteins from insect eggs: structure, biosíntesis and programmed degradation during embryogenesis. Journal of Insect Physiology 40(9): 735-746.

LoiÁCONO, M. S. 1980. Nota sobre tres scelionidos parasitoides de hemipteros de la República Argentina y Brasil (Hymenopteraproctotrupoidea). Revista de la Sociedad Entomologica Argentina 39(3-4):173-178.

Marchiori, C. H. \& Penteado-Dias, A. M. 2002. Nova ocorrência de Gryon gallardoi (Hymenoptera, Scelionidae) parasitóide de Hemiptera em Itumbiara, Goiás, Brasil. Biociências 10(1):177-179.

Navasero, R. \& Oatman, E. 1989. Life history immature morphology and adult behaviour of Telenomus solitus (Hymenoptera: Scelionidae). Entomophaga 34:165-177.

OrR, D. B. 1988. Scelionid wasps as biological control agents: a review. Florida Entomologist 71:506-528.

Orr, D. B.; Russin, J. S. \& Boethel, D. J. 1986. Reproductive biology and behaviour of Telenomus calvus (Hymenoptera: Scelionidae), a phoretic egg parasitoid of Podisus maculiventris (Hemiptera: Pentatomidae). Canadian Entomologist 118:1063-1072.

PAK, G. A. 1986. Behavioral variations among strains of Trichogramma spp. A review of the literature on host age selection. Journal of Applied Entomology 101:55-64.

Pak, G. A.; Buis, C. E. M.; Heck, I. C. C. \& Hermans, M. L. G. 1986. Behavioral variations among strains of Trichogramma spp. Entomologia Experimentalis et Aplicatta 40:247-258.

RabB, R. L. \& Bradley, J. R. 1970. Marking host eggs by Telenomus sphingis. Annals of the Entomological Society of America 63(4):1053-1056.

Romeis, J.; Shanower, T. G. \& Madhuri, K. 2000. Biology and field performance of Gryon cravigrallae (Hymenoptera.: Scelionidae), an egg parasitoid of Clavigralla spp. (Hemiptera: Coreidae) in India. Bulletin of Entomological Research 90:253-263.

Rosi, M. C.; Isidoro, N.; Colazza, S. \& Bin, F. 2001. Source of the host marking pheromone in the egg parasitoid Trissolcus basalis (Hymenoptera: Scelionidae). Journal of Insect Physiology 47:89-995.

Ruberson, J. R. \& Kring, T. J. 1993. Parasitism of developing eggs by Trichogramma pretiosum (Hymenoptera: Trichogrammatidae): Host age preference and suitability. Biological Control 3:39-46.

SALT, G. 1934. Experimental studies in insect parasitism II. Superparasitism. Proceedings of the Royal Society of London, Series B 122:57-75.

Santos, S. S. R.; Redaelli, L. R. \& Diefenbach, L. M. G. 2001 Ocorrência de parasitismo em ovos de Spartocera dentiventris (Berg) (Hemiptera: Coreidae) em cultura de fumo. Neotropical Entomology 30(4):731-733.

Schaefer, C. W. \& PAnizzi, A. R. 2000. Heteroptera of Economic Importance. Florida, CRC. $828 \mathrm{p}$.

Schimid, J. M. \& Sмith, J. J. B. 1987. The measurement of exposed host volume by the parasitoid wasp Trichogramma minutum and the effects of wasp size. Canadian Journal of Zoology 65:2837-2845.

Solis, S. R.; Fagundes, G. G. \& Amaral-Filho, B. F. 2001. Comportamento de oviposição de Gryon gallardoi em ovos de Leptoglossus zonatus. Revista de Agricultura 76(6):451-462.

Souza, C. E. P. \& Amaral-Filho, B. F. 1999. Ocorrência natural de parasitóides de Leptoglossus zonatus (Dallas) (Heteroptera: Coreidae). Anais da Sociedade Entomológica do Brasil 28(4): 757-759.

Strand, M. R. \& Vinson, S. B. 1983. Host acceptance behaviour of Telenomus heliothids (Hymenoptera: Scelionidae) toward Heliothis virescens (Lepdoptera: Noctuidae). Annals of the Entomological Society of America 76(4):781-785.

TAKASU, K. \& Hirose, Y. 1993. Host acceptance behaviour by the host-feeding egg parasitoid Oencirtus nezarae (Hymenoptera: Encyrtidae) host age effects. Entomological 
Society of America 86(1):117-121.

Vinson, S. B. 1998. The general host selection behaviour of parasitoid hymenoptera and a comparasion of initial strategies utilized by larvaphagous and oophagous species. Biological Control 11:79-96.

Weber, C. A.; Smilanick, J. M.; Ehler, L. E. \& Zalom, F. G. 1996. Ovipositional behaviour and host discrimination in three scelionid egg parasitoid of stink bug. Biological Control
6:245-252.

Wiedemann, L. M.; Canto-Silva, C. R.; Romanowski, H. P. \& REDAELLI, L. R. 2003. Oviposition behaviour of Gryon gallardoi (Hym.: Scelionidae) in eggs of Spartocera dentiventris (Hem. Coreidae). Brazilian Journal of Biology 63(1):133-139.

Wu, Z. X. \& Nordlund, D. A. 2002. Superparasitism of Lygus hesperus Knight eggs by Anaphes iole Girault in the laboratory. Biological Control 23:121-126. 